\title{
Character Education Strengthening of Students Through The Mathematical Disposition Strategy on Statistics Elementary
}

\author{
Ahmad Yani $\mathrm{T}^{1)}$, Kurnia Ningsih ${ }^{2)}$ \\ ${ }^{1)}$ Universitas Tanjungpura, Pontianak, Indonesia \\ E-mail:dr.ahmad.yani@gmail.com \\ ${ }^{2)}$ Universitas Tanjungpura, Pontianak, Indonesia \\ E-mail: $\underline{\text { nia_untan@yahoo.com }}$
}

\begin{abstract}
This study aims to improve the strengthening of student character education through a mathematical disposition strategy in Elementary Statistics. The sample of this study was 30 students of the 3rd semester of Biology Education. The research method used was experimental and the research firm was quasi-experimental. Data collection techniques are measurement techniques, namely initial ability tests and mathematical disposition scales. The results of this study indicate that character education can be enhanced or strengthened by a mathematical disposition strategy. That is by increasing high confidence in solving problems, not easily discouraged and asking questions, having prepared before starting learning such as reading the material or other references, knowing the role of mathematics related with everyday life and knowing that success in mathematics subjects can support progress in other disciplines.
\end{abstract}

Keywords: Character, Strengthening, Mathematical Disposition.

\section{INTRODUCTION}

There are three things that the curriculum will achieve, namely (1) character, (2) competence, and (3) literacy. Character quality is about how to deal with a changing environment. Moral character includes priests, honesty, honesty and character of work including discipline, firmness, hard work, responsibility. Competence is about how to overcome complex challenges. Competencies include critical, creative, communicative and collaborative thinking. While literacy is about how to apply core skills to daily activities. Things related to literacy include reading writing, numeracy, scientific literacy, information technology literacy and communication, financial literacy, and cultural literacy and citizenship (Harosid, 2017: 4-5).

Character education is essentially a process of forming human identity which is carried out by building the qualities of logic, morals and faith. Its formation is directed at the process of human liberation from incompetence, untruth, dishonesty, injustice and from bad morals and faith. With this process, it is hoped that human identity will be formed with character, character, and dignity (Mulyasana, 2011: 289).
Today there is concern in some communities about the behavior of Indonesian people who are considered deviant from morals or noble characters. They are no longer able to distinguish between respectable and praiseworthy behavior with despicable and non-dignified deeds. They do not understand or do not care about actions that are considered shameful and despicable, do not care or are unable to distinguish between noble and negative actions (Hidayat, 2011: 445). The development of character education due to failure (1) moral, moral or good values education has not been fully taught, (2) religious education is more about teaching doctrine and the basics of religion, and (3) there are no behavioral practices and application of values kind. Though character education itself is a system of planting character values which include components of knowledge, awareness or willingness, and actions to implement these values. Character education can be interpreted as "the deliberate use of all dimensions of school life to optimal character development". As stated above that in character education in schools, all components must be involved, including the components of education itself, namely the contents of subjects, school management, implementation of activities or 
activities in the curriculum, empowerment of facilities and infrastructure, funding, and work ethic of all residents school/environment (Hidayat, 2011: 445-446).

At present, there are sometimes students who, when faced with lecturers, are kind and obedient, but not the same when at home. In terms of the function of National education, one of which is forming character education. The above case can occur for students only being taught knowledge. But not educated or guided to feel and experience character education like what (Hidayat, 2011: 446). Some students feel proud if the lecture does not have a lecturer, many libraries are empty, the internet is used for things that are not commendable, (Wahyu, 2011: 226). Brawl behavior or violence or other disrespectful behavior in schools or campuses is impossible without problems. With the condition of the inhalation of the nation where human values experience a crisis, if the world of formal education which only educates the life of the nation, without being balanced with the planting of values of nobility of human dignity, has not made a big contribution to the realization of a just and prosperous society.

By the mandate of the 2013 curriculum which focuses on character education, the main objectives of mathematics learning in schools are two, namely formal goals and material goals (Soedjaji, 1992). The formal purpose of mathematics learning is related to the structuring of reasoning and formation of students and the purpose of mathematics learning material related to the assignment of mathematics (skills) in other fields.

Based on the problems described earlier, it shows that character education is very important for students. To improve character education, various methods are carried out in one of them through mathematical dispositions. Mathematical disposition according to Kilpatrick, Swafford, and Findell (in Sumarmo, 2010: 2) is a productive attitude or positive attitude and a habit of seeing mathematics as something logical, useful, and useful. In the context of mathematics, mathematical disposition (mathematical disposition) is related to how students perceive and solve problems; whether confident, diligent, interested, and flexible thinking to explore various alternative solutions to problemsolving. Disposition is also related to the tendency of students to reflect on their own thoughts. Learning mathematics not only learns concepts, procedures, and applications, but also includes developing dispositions towards mathematics and appreciating mathematics as a powerful tool for understanding situations.

According to NCTM (1989: 233) mathematical dispositions include several indicators as follows:

a) confidence in using mathematics to solve problems, to communicate ideas, and to reason.

b) flexibility in exploring mathematical ideas and trying alternative methods in solving problems.

c) willingness to persevere in mathematical tasks.

d) interest, curiosity, and inventiveness in doing mathematics.

e) inclination to monitor and reflect on their own thinking and performance. f) valuing the situation in other disciplines and everyday experiences.

g) the appreciation of the role of mathematics as a tool and as a language.

The assessment of mathematical disposition is contained in the affective domain which is the goal of mathematics education, namely "students have an attitude of appreciating the usefulness of mathematics in life, that is having curiosity, attention, and interest in learning mathematics, as well as being tenacious and confident in problem-solving" (BSPN, 2006: 146). This shows that the importance of mathematical disposition in mathematics learning. However, based on the reality on the ground, education shows a different indication, lecturers are accustomed to learning conventionally, lecturers are merely conveyers of knowledge messages, while students tend to be recipients of knowledge by recording, listening and memorizing, and practicing the questions delivered by the teacher.

\section{A. Character Education}

The term character or in Indonesian is translated by character, is the essential characteristics of a person or a group or nation that is very prominent so that it can be recognized in various situations or is a person's trade mark (Tilaar, 2008).

Lickona (1991) refers to the concept of a goog character which is explained by Arisoteles "... the life of right conduct - right conduct in relations to other persons and in relation to one self (character can be interpreted as a life of good behavior, ie behaving both to others (God Almighty, human beings, and the universe) and to oneself).

Mujib (2006: 45) states that the term character (al-khuluk) in Islamic terminology is "Is one of the psychology of Islamic personality in addition to the original image (al-fitrah), vitality (al-hayah), tabiah (al thab'u ), talent (al-otakyah), traits (al-traits), and behavior (al-'amal) ". Khuluk (character/singular form of morals) is an inner condition (inner) not an outward (external) condition of the individual which includes character (al-thab'u) and talent (al-sajiyah). Khuluk is the condition (hay'ah) in the holy soul (nafs) (rasikhah) requires prior thought and consideration. In the terminology of psychology, character is character, temperament, or characteristic nature; one eternal constant quality or quality that can be used as a feature to identify a person.

Furthermore, in a broader sense, Martadi (2010) states character education is interpreted as value education, character education, moral education, character education, which aims to develop the ability of students to make good decisions, maintain what is good, and realize goodness in everyday life with all my heart. Through character education we want children to be able to judge what is good, maintain sincerely what is said well, and realize what is believed to be good even in situations of stress and temptation (Revelation, 2011: 228). 
Character Education is the process of giving guidance to participants/students to become fully human characters in the heart dimension, leading to moral life and individual moral maturity. In other words, the character is interpreted as a good personal quality, in the sense of knowing goodness, willingness to do good, and real good behavior, which coherently radiates as a result of thought, heart training, sports, taste and intention (Revelation, 2011 : 228). In this study the notion of character education uses this opinion.

\section{B. Mathematical Disposition}

\section{Definition of Mathematical Disposition}

According to Anku (1996: 536) one of the factors that influence the process and results of student mathematics learning is their disposition towards mathematics. Katz (2009: 2) defines disposition as a tendency to behave consciously, frequently, and voluntarily to achieve their goals. These behaviors include being confident, persistent, curious, and thinking flexibly.

Katz (2009: 2), mathematical disposition (mathematical disposition) is related to how students solve mathematical problems; whether confident, diligent, interested, and flexible thinking to explore various alternative solutions to problems. In the context of learning, mathematical dispositions are related to how students ask, answer questions, communicate mathematical ideas, work in groups, and solve problems.

Wardani (2008: 15) defines mathematical disposition is the relationship and appreciation of mathematics, which is the tendency to think and act positively, including selfconfidence, curiosity, perseverance, enthusiasm in learning, persistent problems, flexibility, sharing with others, reflective in doing math. Whereas according to Maxwell (2001: 32), the disposition consists of (1) inclination (tendency), which is how students' attitudes toward tasks; (2) sensitivity (ie sensitivity), which is how students are prepared to face the task; and (3) abilities, namely how students focus to complete the task completely; and (4) enjoyment, which is how students behave in completing tasks.

Students' mathematical dispositions are said to be good if students like problems that are challenges and involve themselves directly in finding/solving problems. In addition, students feel themselves experiencing the learning process when completing the challenge. In the process students feel the emergence of self-confidence, hope and awareness to look back on the results of their thinking.

Student's mathematical disposition is an appreciation of student attitudes towards mathematics which is shown through self-confidence, flexibility, diligence, resilience, and thoroughness in solving problem solving problems.

\section{Indicator of Mathematical Disposition}

The indicators of mathematical disposition stated by NCTM (1989: 233) are:

a. Self-confidence in solving mathematical problems, communicating ideas, and giving reasons. b. Flexibility in exploring mathematical ideas and trying various alternative methods to solve problems.

c. Strong determination to complete mathematical tasks.

d. Interest, curiosity, and ability to find in working on mathematics.

e. The tendency to monitor and reflect on one's own thinking and performance processes.

f. Assessing mathematical applications in other fields and in everyday life.

g. appreciation of the role of mathematics in culture and its value, both mathematics as a tool, and mathematics as a language.

Polking (in Syaban, 129: 2009) suggests several indicators of mathematical disposition including: the nature of selfconfidence and diligence in doing mathematical tasks, solving problems, communicating mathematically, and in giving mathematical reasons; flexibility in investigating, and trying to find alternatives in solving problems; showing interest and curiosity, the nature of wanting to monitor and reflect on the way they think; trying to apply mathematics to other situations, appreciate the role of mathematics in value culture, mathematics as a tool and language. Sumarmo (2010) indicators of mathematical disposition are:

a. Confidence in using mathematics, solving problems, giving reasons and communicating ideas

b. Flexibility in investigating mathematical ideas and trying to find alternative methods in solving problems.

c. Diligently work on math tasks.

d. Having interest, curiosity and meeting power in doing mathematical tasks.

e. Monitor and reflect on the performance performed.

f. Assess the application of mathematics to other situations in mathematics and everyday experience.

g. Appreciating the role of mathematics in culture and mathematical values as a tool and as a language.

h. Based on the indicators of mathematical disposition stated above, indicators of mathematical disposition used in this study are according to NCTM (1989).

\section{RESEARCH METHOD}

Research methods that use experimental methods. The experimental method is used because it matches the research objectives. The form of this study was chosen because researchers did not have the ability to control or manipulate all relevant variables such as student learning interest, intelligence level, and family economic background of each student. (Suryabrata, 2000: 33). The research design used was Only Pre-test and Post-test Control Group Design (Suryabrata, 2000: 35). The sample in this study were 30 semester students of the Biology Education study program. 


\section{- - - Jurnal Pendidikan Matematika Indonesia \\ Volum 4 Nomor 1 bulan Maret 2019 Page 1 - 5 \\ p-ISSN: 2477-5967 e-ISSN: 2477-8443}

\section{RESULT AND DISCUSSION}

To measure the mathematical disposition of students in this study, namely by using seven indicators according to NCTM (1989) namely (a) confidence in solving mathematical problems, communicating ideas, and giving reasons, (b) flexibility in exploring mathematical ideas and trying various alternative methods for solving problems, (c) determined to complete mathematical tasks, (d) interest, curiosity, and ability to find in working on mathematics, (e) tendency to monitor and reflect on processes of thought and selfperformance, ( f) assess mathematical applications in other fields and in everyday life, and $(\mathrm{g})$ appreciation of the role of mathematics in culture and its value, both mathematics as a tool, and mathematics as a language.

In this study, students' mathematical dispositions were divided into five categories, namely very high, high, medium, low, and very low. Based on the data that has been obtained it can be seen that the most included in the category have a high mathematical disposition of 17 people or $57 \%$ of the thirdsemester students of the Biology Education study program.

Based on the results of the analysis of the students' mathematical disposition scale, students belonging to very high mathematical dispositions have very high selfconfidence that is confident and trying to answer the questions posed by the teacher, like working on questions in the form of stories or others in a variety of ways, not easily broken desires and likes to ask if there is material that is poorly understood and like working on practice questions to deepen understanding. Have preparation before starting learning such as reading material and looking for other references. Repeat the lessons learned and associate new material with the material that has been studied. Knowing the role of mathematics related to everyday life and other disciplines. In addition, it also knows that success in mathematics can support success in other subjects

Students who are classified as having high mathematical dispositions have high self-confidence that is confident and trying to answer the questions posed by the teacher, like working on questions in the form of stories or others in a variety of ways, not easily discouraged and like to ask if there is material that is not understood and enjoy working on practice questions to deepen understanding. Have preparation before starting learning such as reading material and looking for other references. Tend to repeat the lessons that have been learned and associate new material with the material that has been studied. Knowing the role of mathematics related to everyday life and other disciplines. In addition, it also knows that success in mathematics can support success in other subjects.

Students who are classified as having a moderate mathematical disposition have good self-confidence, that is, confident and trying to answer the questions posed by the teacher, like working on questions in the form of stories or others in various ways, usually easily discouraged and ashamed to ask if there is material lacking understandable and happy to work on practice questions to deepen understanding. Sometimes it has preparation before starting learning such as reading material and looking for other references. Sometimes repeating lessons learned and linking new material to the material that has been studied. Not yet fully aware of the role of mathematics in relation to everyday life and other disciplines. In addition, it also knows that success in mathematics can support success in other subjects

Based on the results of the initial ability test, mathematical disposition scale and analysis of research results, it can be seen that the mathematical dispositions and initial abilities of each student vary or tend to be the same even though some are not appropriate. Students who have high initial abilities tend to have high mathematical dispositions too. Based on the discussion above, it can be seen that character education can be improved or strengthened by mathematical disposition strategies namely by increasing high self-confidence in solving problems, not easily discouraged and asking questions, having preparation before starting learning such as reading material or other references, knowing the role of mathematics is related to everyday life and knowing that success in mathematics can support success in other subjects.

\section{CONCLUSION}

\section{A. Conclusions}

Based on the results of the research put forward by the researcher, it can generally be concluded that there is an increase in the strengthening of student character education through mathematical disposition strategies in the Elementary Statistics course. The conclusions are more detailed as follows.

1. The results of the tests on the initial ability of thirdsemester students in the Biology Education study field are included in the high category, amounting to 22 people or $77 \%$.

2. The results of the scale of the mathematical disposition of third-semester students in the Biology Education study included in the category of 17 people or $57 \%$.

3. Character education can be improved or strengthened by a mathematical disposition strategy that is by increasing high self-confidence in solving problems, not easily discouraging and asking questions, having preparation before starting learning such as reading material or other references, knowing the role of mathematics in relation to daily life day and know that success on math subjects can support success in other subjects.

\section{B. Suggestions}

Suggestions that need to be conveyed by researchers based on the research that has been carried out are that it is better when filling out the elementary statistical ability test and the character education scale to be supervised so that students answer in earnest 


\section{REFERENCES}

Anku, S.A. 1996. Fastering Student's Disposition towards Mathematics: a Case from a Canadian University. Singapura: 469 Bukit Timah Road.

Badan Standar Nasional Pendidikan. 2006. Panduan Kurikulum Tingkat Satuan Pendidikan (KTSP). Jakarta: BSPN.

Harosid, Harun. 2017. Kurikulum 2013 Revisi 2017.

Hidayat, Mufid. 2011. Pendidkam Karakter: Makna, Restorasi, Permasalahan, dan Upaya Mengatasinya. Upaya Pembinaan Kepribadian. Bandung: Widya Aksara Press.

Katz, L. G. 2009. Disposition as Educational Goals. (Online). (http://www.edpsycinteractive.org/files/edoutcomes.h tml, diakses tanggal 5 April 2018).

Lickona, T. 1991. Education for Character: How Our School can Teach Respect and Responsibility. New York. Bantam Books.

Martadi. 2010. Grand Design Pendidikan Karakter. Makalah pada Sarasehen Nasional Pendidikan Karakter 2010. Koordinator Kopertis Wilayah XI Kalimantan.

Maxwell, John. 2001. Developing the Leader Within You Workbook. New York: Injos, Inc.

Mujib, Abdul. 2006. Kepribadian dalam Psikologi Islam. Jakarta: PT. Raja Grafindo Persada.

Mulyasana, Dedi. 2011. Pendidikan Karakter: Apa, Mengapa dan Bagaimana?. Nilai Inti Bagi Upaya Pembinaan Kepribadian Bangsa. Bandung: Widya Aksara Press.
NCTM. 1989. Curriculum and Evaluation Standards for School Mathematics. Reston, Virginia: NCTM.

Soedjaji. 1992. Memantapkan Matematika Sekolah sebagai Wahana Pendidikan dan Penalaran Kebudayaan. Surabaya: Program Pacsa Sarjana Pendidikan IKIP Surabaya.

Sumarmo, Utari. 2010. Berfikir dan Disposisi Matematik: Apa, Mengapa, dan Bagaimana Dikembangkan pada Peserta Didik. (Online). (http://www.academia.edu, diakses tanggal 5 April 2018).

Suryabrata, Sumadi. 2010. Metode Penelitian. Jakarta: PT. Raja Grafindo Persada.

Syaban, M. 2009. Menumbuhkembangkan Daya dan Disposisi Siswa SMA Melalui Pembelajaran Investigasi. (Online) (http://www.uai.no/no/content/download/2math.html, diakses tanggal 5 April 2018).

Tilaar, HAR. 2008. Karakteristik Bangsa dalam Perspektif Pedagogik Kontemporer, dalam Saifudin dan Karim, Refleksi Karakter Bangsa. Jakarta: Forum Kajian Antropologi Indonesia.

Wahyu. 2011. Masalah dan Usaha Membangun Karakter Bangsa. Nilai Inti Bagi Upaya Pembinaan Kepribadian. Bandung: Widya Aksara Press.

Wardani, S. 2008. Meningkatkan Kemampuan Berfikir Kreatif dan Disposisi Matematik Siswa SMA Melalui Pembelajaran Dengan Pendekatan Model Sylver. (Online). (http://www.matedu.cinvestav.mx/adalira.pdf, diakses tanggal 5 April 2018). 